\title{
HELLP syndrome: a complication or a new autoimmune syndrome?
}

\section{Zespót HELLP: powikłanie czy nowy zespół autoimmunologiczny?}

\author{
Paola Triggianese ${ }^{1}$, Carlo Perricone ${ }^{2}$, Roberto Perricone ${ }^{1}$, Caterina De Carolis ${ }^{3}$ \\ ${ }^{1}$ University of Rome Tor Vergata, Rheumatology, Allergology and Clinical Immunology, Department of "Medicina dei Sistemi”, \\ Rome, Italy \\ ${ }^{2}$ Reumatologia, Dipartimento di Medicina Interna e Specialità Mediche, Sapienza Università di Roma, Rome, Italy \\ ${ }^{3}$ Gynaecology and Obstetrics II, San Giovanni-Addolorata Hospital, Rome, Italy
}

Key words: HELLP syndrome, pregnancy complication, therapeutic options.

Słowa kluczowe: zespół HELLP, powikłania ciąży, możliwości terapeutyczne.

\begin{abstract}
Summary
The HELLP (hemolysis, elevated liver enzymes, low platelets) syndrome is a pregnancy-specific disease characterized by hemolysis with elevated lactate dehydrogenase, elevated liver enzymes, and decreased platelet count. It is considered a severe variant of the hypertensive disorders that occur during pregnancy together with the pre-eclampsia (PE) and the eclampsia giving symptoms in the mother from 20 weeks' gestation onward. All these conditions are multi-system pregnancy-related diseases associated with an increase in blood pressure and in both the perinatal and the maternal morbidity/mortality. Observational studies suggest that steroid treatment in HELLP syndrome may improve the hematological and biochemical features in the mother and the perinatal outcome. The present review aims to show that the HELLP syndrome may be considered as an autoimmune disorder itself. Biomarkers of the immune system can be a useful tool improving the diagnostic and therapeutic management of women with HELLP by delineating the underlying etiology of this syndrome.
\end{abstract}

\section{Introduction}

Pregnancy-associated diseases with placental origin are multifactorial conditions to which both maternal and feto-placental factors contribute, and the combination of these factors leads to differences in disease features. These diseases have a familial component suggesting a genetic background. Hypertensive disorders of preg-

\section{Streszczenie}

Zespół HELLP (hemolysis, elevated liver enzymes, low platelets) jest schorzeniem występującym u kobiet w ciąży. Składają się na niego następujące objawy: hemoliza ze zwiększonym stężeniem dehydrogenazy mleczanowej, zwiększonym stężeniem enzymów wątrobowych oraz obniżona liczba płytek krwi. Zespół HELLP uznawany jest za ciężką postać zaburzeń nadciśnieniowych wywołanych ciążą, do których należą także stan przedrzucawkowy oraz rzucawka. Objawy zaburzeń zaczynają pojawiać się od 20. tygodnia ciąży. Wszystkie te choroby mają charakter wieloukładowy, specyficzny dla ciąży i wiążą się ze wzrostem ciśnienia krwi oraz podwyższoną chorobowością/śmiertelnością noworodków i matek. Badania obserwacyjne wskazują, że leczenie zespołu HELLP lekami steroidowymi może przynieść poprawę parametrów hematologicznych i biochemicznych u matek, a także poprawę rokowania u noworodków. Celem niniejszej pracy jest wykazanie, że zespół HELLP można uznać za niezależne schorzenie autoimmunologiczne. Biomarkery immunologiczne mogą być użytecznym narzędziem usprawniającym diagnostykę i leczenie kobiet z zespołem HELLP dzięki określeniu etiologii leżącej u podłoża tego zespołu.

nancy (HDP) include gestational hypertension, generally defined as new-onset hypertension ( $\geq 140 \mathrm{mmHg}$ systolic or $\geq 90 \mathrm{mmHg}$ diastolic blood pressure) arising after 20 gestational weeks (GW), and pre-eclampsia (PE), defined as gestational hypertension accompanied by proteinuria (excretion of $\geq 300 \mathrm{mg}$ protein every 24 hours) [1, 2]. Poor early placentation is especially associated with an early disease onset. Hypertensive 
disorders of pregnancy are among of the major causes of maternal and perinatal morbidity and mortality, and increase the future risk of cardiovascular disease for both mother and offspring. Moreover, predisposing cardiovascular or metabolic risks for endothelial dysfunction, as part of an enhanced systemic inflammatory response, might dominate in the origin of late onset PE. Meta-analyses of epidemiological studies investigating the association between exposure to ambient air pollution and pregnancy-induced hypertensive disorders including gestational hypertension and PE report that exposure to air pollution (in particular nitrogen oxides and particulate matter) increases the risk of HDP [3]. The HELLP syndrome is a pregnancy-specific disease characterized by hemolysis (due to microangiopathic hemolytic anemia), elevated lactate dehydrogenase (LDH), elevated liver enzymes caused by acute liver damage, and a platelet count decreased by the enhanced consumption [4]. It is considered a severe variant of hypertensive disorders in pregnancy together with the PE and the eclampsia that affect maternal and perinatal mortality and morbidity. HELLP occurs in $0.01-0.2 \%$ of the general population, accounting for $10 \%$ to $12 \%$ of complicated gestations with PE or eclampsia. The Tennessee Classification diagnostic criteria for HELLP include hemolysis, increased LDH and liver enzymes, and a low platelet count. The Mississippi Triple-class Classification criteria further classify the disease by the nadir of the platelet count [5]. It is well known that alterations in the placenta and in the trophoblast invasion of spiral arteries have a central role, but the utero-placental lesions seem to be not specific to hypertensive disorder alone. Thus, there is an increasing interest in the role of the inflammatory and the immunologic mechanisms involved in the pathogenesis of the HELLP syndrome.

\section{Inflammation and antioxidant mechanisms}

Hypertensive disorders of pregnancy are characterized by metabolic disturbances similar to those found in cardiovascular diseases including endothelial dysfunction, inflammation, and oxidative stress [1]. Prospective longitudinal studies of cytokine expression in the circulation during normal pregnancy show that as pregnancy progresses, there is an overall decrease in pro-inflammatory cytokines such as tumor necrosis factor $\alpha$ (TNF- $\alpha)$ and interferon $\gamma$ (IFN- $\gamma$ ), accompanied by an increase in the anti-inflammatory cytokines such as interleukin 10 (IL-10) [6]. The balance between pro- and anti-inflammatory cytokines is essential for implantation, placental development and pregnancy outcome. Changes in the $T$ helper (h)1/Th2 balance in the fe- to-maternal interface in favor of Th1 can lead to adverse pregnancy outcomes, including recurrent spontaneous miscarriages [7, 8]. Increased Th1 cytokines, including TNF- $\alpha$, have been found in women suffering from recurrent spontaneous abortion (RSA) [7, 8]. Evidence suggests that inflammatory cytokines deriving from placenta such as TNF- $\alpha$, interleukin IL- 6 and IL-10 are increased during pregnancy-induced hypertension [8]. However, it is well known that immune cells communicate by cytokines and chemokines and that these interactions influence the immune differentiation and activation. Inflammatory cytokines and $T$ lymphocytes have recently been reported to be involved in animal models of HELLP syndrome: HELLP rats show increased plasma levels of TNF- $\alpha$, IL-6 and IL-17, and CD8+T lymphocytes [9]. Disorders in the cytokine and chemokine expression and alterations in the cell signaling may be involved in the alteration of the placenta function in terms of angiogenesis, cell recruitment, and lymphoid trafficking (Fig. 1). In the context of cellular signaling pathways, evidence suggests a role of the mitogen-activated protein kinases (MAPKs), a family of serine/threonine kinases, in the organogenesis of the placenta [10]. In human placenta, p38a MAPK is activated by a variety of extracellular stimuli such as inflammatory cytokines (IL-1, TNF- $\alpha$ ) and growth factors, UV irradiation, high osmotic stress, and chemical agents. Adams et al. show that the loss of p38a MAPK causes placental defects and embryonic death [11]. The authors documented that placental p38a MAPK is significantly lower in the HELLP syndrome compared with the controls suggesting a correlation between the p38a MAPK gene and the development of placental insufficiency as occurs in HELLP syndrome [10]. Heat shock proteins (Hsps) are ubiquitous molecules that are usually considered to be intracellular proteins with molecular chaperone and cytoprotective functions. However, Hsp70 (HSPA1A) is present in the peripheral circulation of healthy non-pregnant and pregnant individuals [12]. In normal pregnancy, circulating Hsp70 levels are decreased and show a positive correlation with gestational age and an inverse correlation with maternal age [13]. The capacity of extracellular Hsp70 to elicit innate and adaptive pro-inflammatory immune responses involving the conversion of dendritic cells (DCs) from tolerogenic to immunogenic and the stimulation of the cytolytic activity of natural killer (NK) cells and $\gamma / \delta$ T cells might be harmful in pregnancy, and may lead to maternal immune rejection of the fetus [12, 14]. A decreased circulating Hsp70 level, consequently, may promote the maintenance of immunological tolerance to the fetus. Indeed, elevated circulating Hsp70 concentrations are associated with an increased risk of several pregnancy complications. Molvarec et al. report that 


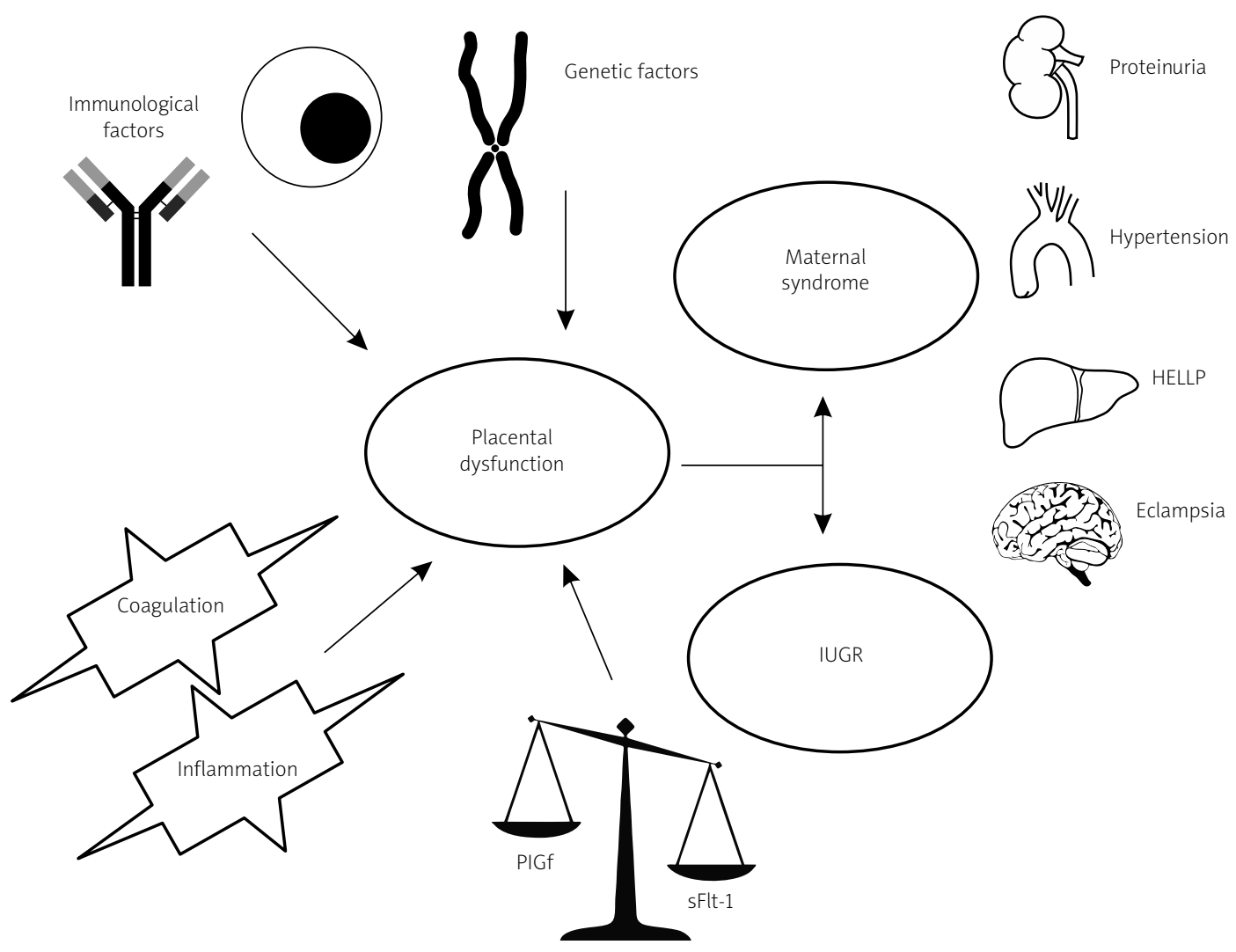

Fig. 1. Pregnancy-associated diseases with placental origin are multifactorial diseases to which both maternal and feto-placental factors contribute, and the combination of these factors leads to differences in disease features.

IUGR - intra-uterine growth retardation; HELLP - hemolysis, elevated liver enzymes, low platelets; sFlt-1 - soluble vascular endothelial growth factor receptor-1; PIGF - placental growth factor

serum Hsp70 levels are significantly higher in patients with HELLP syndrome than in severely pre-eclamptic patients without HELLP syndrome [13]. Furthermore, serum Hsp70 levels show a very strong correlation with the markers of hemolysis (plasma free hemoglobin level, serum LDH activity and total bilirubin level) and of hepatocellular injury (serum aminotransferase activities, such as aspartate aminotransferase, AST, and alanine aminotransferase, ALT) in the HELLP syndrome. Moreover, circulating Hsp70 concentration may also reflect the severity of the disease [15]. Extracellular Hsp70 can stimulate pro-inflammatory cytokine (TNF- $\alpha, \mathrm{IL}-1 \beta$, and IL-6) production of antigen-presenting cells and can also activate the classical complement pathway $[16,17]$. Increasing attention in the physiopathology of inflammatory and immune-mediated diseases has been focused on the role of reactive oxygen species (ROS) since they are produced during inflammation. Glutathione $(\mathrm{GSH})$ is the most abundant non-protein intracellular thiol which acts to scavenge ROS as well as to regenerate other antioxidants from their oxidized forms. Glutathione exerts diverse effects on the immune system, either stimulating or inhibiting the immunological response in order to control inflammation [18]. It is well reported that GSH acts in association with ROS and the complement system (CS) in modulating the inflammatory response mediated by NFKB: GSH inhibits complement-ROS mediated JNK (c-jun-N-terminal kinase/stress-activated protein) in a dose-dependent fashion, resulting in interference with apoptosis [18]. Glutathione acts in association with the CS in modulating the inflammatory response [19]. It is well reported that GSH levels are decreased in the HELLP syndrome [20]. These findings are relevant for the design of interventions aimed at the modulation of GSH metabolism to inhibit CS-mediated damage in autoimmune diseases [19, 20].

\section{The complement system and the innate immune cells}

The CS is involved in the pathogenesis of several autoimmune diseases. Complement activation contrib- 
utes to inflammation-driven tissue injury, which occurs during the ischemia/reperfusion processes, vasculitides, nephritis, arthritis, and many others diseases [21]. It is known that during normal pregnancy, the CS is activated at the maternal-fetal interface through the relative hypoxia as well as the presence of externalized phosphatidylserine on the outer leaflets of trophoblast. CS dysregulation has an essential and causative role in damage to the fetal-placental unit [22]. Evidence confirmed the role of both the classic and the alternative pathway of CS in the initiation of the cascade and the contribution to fetal damage in experimental models and provided evidence linking the CS to angiogenic factor imbalance associated with placental dysfunction [22]. Therefore, biomarkers of CS dysregulation may prove useful for prediction or treatment of complicated pregnancies such as PE/HELLP syndrome [23]. Decreased GSH levels can modulate the immune response influencing the proliferation of NK cells [24]. NK cells are the predominant leukocyte population in the endometrium at the time of implantation and in early pregnancy $[25,26]$. The role of NK cells has been reported to be immunosurveillance; these cells may also mediate the angiogenesis necessary for continuation of the pregnancy or for the remodeling of the spiral arteries to uteroplacental arteries [24]. In this context, evidence supports a key role of the innate rather than adaptive immunity in the pathogenesis of $P E$, in particular the increase of circulating neutro- phils and monocytes, and NK cells [27]. Inhibitory and activating receptors such as immunoglobulin-like (KIR), C-type lectin and natural cytotoxicity receptors, could play a role in the course of the systemic inflammatory response observed in PE $[28,29]$. Indeed, patients with early-onset severe PE without HELLP syndrome have increased NK cell function related to cytokine production, cytotoxicity and expression of lectin-like receptors such as NKG2 [30]. Abnormalities in number and activation of NK cells have also been related to RSA suggesting a possible pathogenic role of these cells in this condition [30]. According to evidence in the literature comparing the percentage of peripheral blood NK cells in infertile and RSA women versus fertile controls, we previously reported that women with reproductive failure show significantly higher NK cell levels than controls [31-34]. Furthermore, evidence in the literature documented that the state of activation of decidual DC represents one of the central players influencing the immunological mechanisms in the pathogenesis of HELLP syndrome [35].

\section{Gene variants and autoimmunity}

HELLP has a hereditary familial component [36]. The genetic contribution is likely complex, involving genetic variants and fetal-maternal gene-gene interactions. Several gene variants are probably associated with increased risk of HELLP syndrome: the vascular endothe-

Table I. Therapeutic options in preclampsia/HELLP syndrome under investigation

\begin{tabular}{|c|c|c|c|c|c|}
\hline $\begin{array}{l}\text { Therapeutic } \\
\text { intervention }\end{array}$ & Conditions & Study design & Phase & Status & $\begin{array}{l}\text { ClinicalTrials.gov } \\
\text { identifiers }\end{array}$ \\
\hline Dexamethasone & $\begin{array}{l}\text { Women with class I HELLP } \\
\text { syndrome }\end{array}$ & $\begin{array}{l}\text { Double-blind, place- } \\
\text { bo-controlled, RCT }\end{array}$ & IV & $\begin{array}{l}\text { Recruiting } \\
\text { participants }\end{array}$ & NCT00711841 \\
\hline Dexamethasone & $\begin{array}{l}\text { Women with class I HELLP } \\
\text { syndrome }\end{array}$ & $\begin{array}{l}\text { Double-blind, place- } \\
\text { bo-controlled, RCT }\end{array}$ & III & Unknown & NCT01138839 \\
\hline Dexamethasone & Women with eclampsia & $\begin{array}{l}\text { Double-blind, place- } \\
\text { bo-controlled, RCT }\end{array}$ & - & Terminated & NCT02027272 \\
\hline LMWH and ASA & $\begin{array}{l}\text { Women with a previous history } \\
\text { of PE }\end{array}$ & $\begin{array}{l}\text { Multicenter prospective } \\
\text { RCT }\end{array}$ & III & $\begin{array}{l}\text { Recruiting } \\
\text { participants }\end{array}$ & NCT00986765 \\
\hline ASA & $\begin{array}{l}\text { Nulliparous pregnant women } \\
\text { selected as "high-risk" for } \\
\text { pregnancy complications }\end{array}$ & $\begin{array}{l}\text { Double-blind, placebo- } \\
\text { controlled, RCT }\end{array}$ & IV & $\begin{array}{l}\text { Recruiting } \\
\text { participants }\end{array}$ & NCT01729468 \\
\hline ASA & $\begin{array}{l}\text { Pregnant women with a previ- } \\
\text { ous history of PE }\end{array}$ & Double-blind, RCT & IV & $\begin{array}{l}\text { Ongoing, not } \\
\text { recruiting }\end{array}$ & NCT01352234 \\
\hline $\begin{array}{l}\text { Antioxidants vitamin } \\
\mathrm{C} \text { and vitamin } \mathrm{E}\end{array}$ & $\begin{array}{l}\text { Hypertensive pregnant patients } \\
\text { and patients with a past history } \\
\text { of PE/eclampsia, HELLP }\end{array}$ & $\begin{array}{l}\text { Double-blind, place- } \\
\text { bo-controlled, RCT }\end{array}$ & III & Completed & NCT00097110 \\
\hline $\begin{array}{l}\text { Antioxidants vitamin } \\
\mathrm{C} \text { and vitamin } \mathrm{E}\end{array}$ & $\begin{array}{l}\text { Low-risk nulliparous pregnant } \\
\text { women, to prevent PE }\end{array}$ & $\begin{array}{l}\text { Double-blind, place- } \\
\text { bo-controlled, RCT }\end{array}$ & III & Completed & NCT00135707 \\
\hline
\end{tabular}

HELLP - hemolysis, elevated liver enzymes, low platelets; RCT - randomized clinical trial; PE - preclampsia; LMWH - low molecular weight heparin; ASA - acetylsalicylic acid 
lial growth factor (VEGF) gene, the coagulation factor $V$ Leiden mutation, the glucocorticoid receptor gene, and the Toll-like receptor gene [5]. These variants contribute to altered immune regulation and apoptosis, defects in angiogenesis and vasculogenesis, uncontrolled inflammation, and thrombophilia [5]. Several maternal risk factors are probably associated with a higher risk of HELLP syndrome such as the metabolic syndrome, infertility treatment, as well as the presence of autoimmune diseases. Metabolic disorders and cardiovascular risk factors might dominate in the origin of late onset $\mathrm{PE}$, since it seems to be related to endothelial cell dysfunction as well as systemic vascular resistance [37]. An imbalance between anti-angiogenic factors (e.g. soluble VEGF receptor-1, s-Flt1, and soluble endoglin, s-Eng) and pro-angiogenic factors (e.g. placental growth factor PIGF) has been associated with PE [38]. Many biomarkers are reported in maternal blood predicting early onset HELLP syndrome such as an abnormal concentration of the placental protein 13 (PP13) and angiogenic factors (VEGF, s-Flt1, s-Eng) [39, 40]. Moreover, meta-analyses on non-classical cardiovascular biomarkers after HDP suggest persistent endothelial inflammation [41]. Women with rheumatologic diseases are more likely to have PE and miscarriage than healthy women [42]. Appenzeller et al. reported the relationship between HELLP syndrome, antiphospholipid syndrome (APS) and antiphospholipid (aPL) antibodies [43]. The APS is an autoimmune disease characterized by one or more aPL which react towards negatively charged plasmatic proteins and many components of coagulation (platelets, endothelial cells, humoral factors). Targets of aPL are phosphatidylserine, protein $\mathrm{C}$ and $\mathrm{S}$, antithrombin III, prothrombin, annexin $\mathrm{V}$, and $\beta_{2}$ glycoprotein I [44]. The relationship between HELLP syndrome and APS is well described, and HELLP syndrome can be considered in the group of thrombotic microangiopathy as a microangiopathic APS [43].

\section{Diagnosis and therapeutic options}

Main diagnostic criteria of the HELLP syndrome in clude the Tennessee Classification and the Mississippi Triple-class System. According to the Tennessee Classification, the following criteria should be satisfied: microangiopathic hemolytic anemia with abnormal blood smear, low serum haptoglobin and elevated LDH levels, a platelet count below $100 \times 10^{9} /$, an elevation of AST above $70 \mathrm{IU} / \mathrm{I}$ and LDH above $600 \mathrm{IU} / \mathrm{I}$ or bilirubin more than $1.2 \mathrm{mg} / \mathrm{dl}$ [45]. In the Mississippi Triple-class System, there are three classes of HELLP syndromes according to the nadir of the platelet count: class 1 includes a platelet count below $50 \times 10^{9} /$; class 2 includes a plate- let count below $100 \times 10^{9} /$; class 3 includes a platelet count below $150 \times 10^{9} / \mathrm{l}$ [46]. There are several conditions in differential diagnosis with HELLP: pregnancy-related diseases (benign thrombocytopenia and acute fatty liver of pregnancy); infectious, inflammatory diseases not specifically related to pregnancy (virus hepatitis, cholangitis, cholecystitis); diseases characterized by thrombocytopenia (immunologic thrombocytopenia, folate deficiency, systemic lupus erythematosus, APS); and diseases that may mimic HELLP (thrombotic thrombocytopenic purpura and hemolytic uremic syndrome). The efficacy of corticosteroids (which can reduce inflammation and improve maternal platelet count) in the HELLP syndrome confirms the role of the inflammatory and angiogenic imbalance as well as of immune-abnormalities in the pathophysiology of the HELLP syndrome $[47,48]$. Moreover, the strategy of treatment in APS and HELLP patients is similar and still a matter of debate: aspirin, low molecular weight heparin, plasma exchange, fresh frozen plasma administration, and intravenous immunoglobulins have been considered in the management of HELLP treatment. The use of antithrombin has also been suggested as a possible therapeutic option. Therapeutic options targeting the underlying immunologic mechanisms during PE/HELLP syndrome that are under investigation are summarized in Table I.

To conclude, HELLP syndrome has been for too long described just as a clinical complication of pregnancy. The unveiling of the (auto)immune pathogenic mechanisms underlying its onset is crucial for correct management and the development of effective therapies.

The authors declare no conflict of interest.

\section{References}

1. Cunningham FG, Leveno KJ, Bloom SL, et al. Pregnancy hypertension. In: Williams Obstetrics. Cunningham FG, Leveno KJ, Bloom SL, et al. (eds.). 23rd ed. McGraw Hill; USA 2009.

2. Steegers EA, von Dadelszen P, Duvekot JJ, Pijnenborg R. Pre-eclampsia. Lancet 2010; 376: 631-644.

3. Pedersen M, Stayner L, Slama R, et al. Ambient air pollution and pregnancy-induced hypertensive disorders: a systematic review and meta-analysis. Hypertension 2014; 64: 494-500.

4. Audibert F, Friedman SA, Frangieh AY, Sibai BM. Clinical utility of strict diagnostic criteria for the HELLP (hemolysis, elevated liver enzymes, and low platelets) syndrome. Am J Obstet Gynecol 1996; 175: 460-464.

5. Abildgaard U, Heimdal K. Pathogenesis of the syndrome of hemolysis, elevated liver enzymes, and low platelet count (HELLP): a review. Eur J Obstet Gynecol Reprod Biol 2013; 166: 117-123.

6. Denney JM, Nelson EL, Wadhwa PD, et al. Longitudinal modulation of immune system cytokine profile during pregnancy. Cytokine 2010; 53: 170-177. 
7. Shaarawy M, Nagui AR. Enhanced expression of cytokines may play a fundamental role in the mechanisms of immunologically mediated recurrent spontaneous abortion. Acta Obstet Gynecol Scand 1997; 76: 205-211.

8. Calleja-Agius J, Muttukrishna S, Jauniaux E. The role of tumor necrosis factor-receptors in pregnancy with normal and adverse outcome. Int J Interferon Cytokine Mediator Res 2012; 4: 1-15.

9. Wallace K, Morris R, Kyle PB, et al. Hypertension, inflammation and $T$ lymphocytes are increased in a rat model of HELLP syndrome. Hypertens Pregnancy 2014; 33: 41-54.

10. Corradetti A, Saccucci F, Emanuelli $M$, et al. The role of p38alpha mitogen-activated protein kinase gene in the HELLP syndrome. Cell Stress Chaperones 2010; 15: 95-100.

11. Adams RH, Porras A, Alonso G, et al. Essential role of p38alpha MAP kinase in placental but not embryonic cardiovascular development. Mol Cell 2000; 6: 109-116.

12. Molvarec A, Tamási L, Losonczy G, et al. Circulating heat shock protein 70 (HSPA1A) in normal and pathological pregnancies. Cell Stress Chaperones 2010; 15: 237-247.

13. Molvarec A, Rigo J Jr, Nagy B, et al. Serum heat shock protein 70 levels are decreased in normal human pregnancy. J Reprod Immunol 2007; 74: 163-169.

14. Pockley AG. Heat shock proteins as regulators of the immune response. Lancet 2003; 362: 469-476.

15. Madach K, Molvarec A, Rigo J Jr, et al. Elevated serum 70 kDa heat shock protein level reflects tissue damage and disease severity in the syndrome of hemolysis, elevated liver enzymes, and low platelet count. Eur J Obstet Gynecol Reprod Biol 2008; 139: 133-138.

16. Asea A, Kraeft SK, Kurt-Jones EA, et al. HSP70 stimulates cytokine production through a CD14-dependant pathway, demonstrating its dual role as a chaperone and cytokine. Nat Med 2000; 6: 435-442.

17. Prohaszka Z, Singh M, Nagy K, et al. Heat shock protein 70 is a potent activator of the human complement system. Cell Stress Chaperones 2002; 7: 17-22.

18. Perricone C, De Carolis C, Perricone R. Glutathione: a key player in autoimmunity. Autoimmun Rev 2009; 8: 697-701.

19. Perricone C, De Carolis C, Giacomelli R, et al. Inhibition of the complement system by glutathione: molecular mechanisms and potential therapeutic implications. Int J Immunopathol Pharmacol 2011; 24: 63-68.

20. Knapen MF, Mulder TP, Van Rooij IA, et al. Low whole blood glutathione levels in pregnancies complicated by preeclampsia or the hemolysis, elevated liver enzymes, low platelets syndrome. Obstet Gynecol 1998; 92: 1012-1015.

21. Chimenti MS, Ballanti E, Triggianese P, Perricone R. Vasculitides and the Complement System: a Comprehensive Review. Clin Rev Allergy Immunol 2014; doi 10.1007/s12016-0148453-8.

22. Girardi G, Yarilin D, Thurman JM, et al. Complement activation induces dysregulation of angiogenic factors and causes fetal rejection and growth restriction. J Exp Med 2006; 203: 2165-2175.

23. Burwick RM, Feinberg BB. Eculizumab for the treatment of preeclampsia/HELLP syndrome. Placenta 2013; 34: 201-203.

24. Perricone C, De Carolis C, Perricone R. Pregnancy and autoimmunity: a common problem. Best Pract Res Clin Rheumatol 2012; 26: 47-60.
25. Perricone R, De Carolis C, Perricone C, Shoenfeld Y. NK cells in autoimmunity: a two-edg'd weapon of the immune system. Autoimmun Rev 2008; 7: 384-390.

26. Konova $E$. The role of NK cells in the autoimmune thyroid disease-associated pregnancy loss. Clinic Rev Allergy Immunol 2010; 39: 176-184.

27. Borzychowski AM, Croy BA, Chan WL, et al. Changes in systemic type 1 and type 2 immunity in normal pregnancy and pre-eclampsia may be mediated by natural killer cells. Eur J Immunol 2005; 35: 3054-3063.

28. Colonna M, Jonjic S, Watzl C. Natural killer cells: fighting viruses and much more. Nat Immunol 2011; 12: 107-110.

29. Riederer I, Sievert W, Eissner G, et al. Irradiation-induced up-regulation of HLA-E on macrovascular endothelial cells confers protection against killing by activated natural killer cells. PLoS ONE 2010; 5: 15339.

30. Bueno-Sánchez JC, Agudelo-Jaramillo B, Escobar-Aguilerae LF, et al. Cytokine production by non-stimulated peripheral blood NK cells and lymphocytes in early-onset severe pre-eclampsia without HELLP. J Reprod Immunol 2013; 97: 223-231.

31. Perricone C, De Carolis C, Giacomelli R, et al. High levels of NK cells in the peripheral blood of patients affected with antiphospholipid syndrome and recurrent spontaneous abortion: a potential new hypothesis. Rheumatology 2007; 46: 15741578.

32. Perricone R, Di Muzio G, Perricone C, et al. High levels of peripheral blood NK cells in women suffering from recurrent spontaneous abortion are reverted from high-dose intravenous immunoglobulins. Am J Reprod Immunol 2006; 55: 232-239.

33. Seshadri S, Sunkara SK. Natural killer cells in female infertility and recurrent miscarriage: a systematic review and meta-analysis. Hum Reprod Update 2014; 20: 429-438.

34. Triggianese P, Perricone C, Perricone R, De Carolis C. Prolactin and Natural Killer Cells: Evaluating the Neuroendocrine-immune Axis in Women with Primary Infertility and Recurrent Spontaneous Abortion. Am J Reprod Immunol 2014; doi:10.1111/aji.12335

35. Scholz C, Toth B, Santoso L, et al. Distribution and maturity of dendritic cells in diseases of insufficient placentation. Am J Reprod Immunol 2008; 60: 238-245.

36. van Dijk M, Oudejans C. (Epi)genetics of pregnancy-associated diseases. Front Genet 2013; 4: 180.

37. Robillard PY, Dekker G, Chaouat G, Hulsey TC. Etiology of preeclampsia: maternal vascular predisposition and couple disease - mutual exclusion or complementarity? J Reprod Immunol 2007; 76: 1-7.

38. Reyes LM, García RG, Ruiz SL, et al. Angiogenic imbalance and plasma lipid alterations in women with preeclampsia from a developing country. Growth Factors 2012; 30: 158-166.

39. Wortelboer EJ, Koster MP, Cuckle HS, et al. First-trimester placental protein 13 and placental growth factor: markers for identification of women destined to develop early-onset pre-eclampsia. BJOG 2010; 117: 1384-1389.

40. Bussen S, Bussen D. Influence of the vascular endothelial growth factor on the development of severe pre-eclampsia or HELLP syndrome. Arch Gynecol Obstet 2011; 284: 551-557.

41. Visser S, Hermes W, Ket JC, et al. Systematic review and metaanalysis on nonclassic cardiovascular biomarkers after hyper- 
tensive pregnancy disorders. Am J Obstet Gynecol 2014; 211 : 373.e1-373.e9.

42. Wolfberg AJ, Lee-Parritz A, Peller AJ, Lieberman ES. Association of rheumatologic disease with preeclampsia. Obstet Gynecol 2004; 103: 1190-1193.

43. Appenzeller S, Souza FH, Wagner Silva de Souza A, et al. HELLP syndrome and its relationship with antiphospholipid syndrome and antiphospholipid antibodies. Semin Arthritis Rheum 2011; 41: 517-523.

44. Gómez-Puerta JA, Cervera R. Diagnosis and classification of the antiphospholipid syndrome. J Autoimmun 2014; 48-49: 20-25.

45. Haram K, Svendsen E, Abildgaard U. The HELLP syndrome: clinical issues and management. A Review. BMC Pregnancy Childbirth 2009; 9: 8.

46. Martin JN Jr, Rinehart BK, May WL, et al. The spectrum of severe preeclampsia: comparative analysis by HELLP (hemolysis, elevated liver enzyme levels, and low platelet count) syndrome classification. Am J Obstet Gynecol 1999; 180: 1373-1384.

47. Woudstra DM, Chandra S, Hofmeyr GJ, Dowswell T. Corticosteroids for HELLP (hemolysis, elevated liver enzymes, low platelets) syndrome in pregnancy. Cochrane Database Syst Rev 2010; 9: CD008148.

48. Wallace K, Martin JN Jr, Tam Tam K, et al. Seeking the mechanism(s) of action for corticosteroids in HELLP syndrome: SMASH study. Am J Obstet Gynecol 2013; 208: 380.e1-380. e8. 